\title{
ECO-HOMESTAY; CONCEPT AND DEVELOPMENT AT PASIRMULYA TOURIST VILLAGE, BANJARAN, BANDUNG - WEST JAVA
}

\author{
Trias Septyoari Putranto ${ }^{1 *}$, Tri Wiyana ${ }^{1}$, Arif Zulkarnain ${ }^{1}$ \\ Hotel Management Department, Faculty of Economic and Communication \\ Bina Nusantara University, Jakarta 11480 Indonesia \\ *tputranto@binus.edu
}

\begin{abstract}
Rural areas experience an imbalance between rural development and cities due to a centralistic development approach. Noting this reality, the government shifted its approach to development strategies that led to decentralization policies. The development of tourism in the village of Pasirmulya is directed at the concept of sustainable development, where local communities are given the authority to manage the tourism potential that exists. The problem is that there are no accommodation facilities for visitors in the village of Pasirmulya, according to the character of rural areas. Eco-homestay is the concept of accommodation facilities in the local ecotourism destination area which is natural, clean, healthy, safe, orderly and environmentally friendly. Applied the concept of marketing, understanding the values of tourism, and improving the quality of human resources, is expected to contribute economically to local communities in the village of Pasirmulya. The results of mentoring that have been carried out are the ability of the community in tourism awareness, can carry out independent cleaning of the homestay and increase income in homestay management.
\end{abstract}

Keywords: Eco-homestay, development, tourist village, Pasirmulya

\section{INTRODUCTION}

Statistical data as of January to December 2015 shows that Indonesia's tourism development achievements are able to exceed predetermined targets. This was evidenced by foreign tourist visits which increased to 10.4 million people, from the 2015 target of 10 million people. The foreign tourist visit contributed to foreign exchange revenue of Rp. 144 trillion (Kementrian Pariwisata, 2016). The village has the potential of natural attraction, culture and local wisdom and daily life of the community, as a strength and uniqueness of tourist attraction. Around 120 million Indonesians live in rural areas and 17.9 million are classified as poor ( (Biro Pusat Statistik, 2015). The search for a tourist village for tranquility, rest and recreation is a common trend in current tourism practices in regional, national, European and international, so that most of the rural tourism countries give major attention to regional development policies. Tourism in rural areas and communities is an alternative to be considered for two reasons: first village, and in other cities. Tourism villages will be able to solve problems by considering: policies regarding planning, village-city balance, realizing such social changes that enable city dwellers to find roots, cultural values, relaxation, lost or forgotten tranquility ( (Dragulanescu \& Drutu, 2012).

The government shifts its approach to development strategies that lead to decentralization policies. This decentralization is important because the region can try to minimize the current imbalance of development results with the issuance of the Act. NO. 32/2004. This law stipulates that decentralization or regional autonomy is one of the solutions to the lack of attention of regions so far. This happens because the effect of centralization development makes the city experience a higher population density due to the opening of employment opportunities in various fields.

Pasirmulya Village is administratively included in Banjaran District, Bandung Regency. The Spatial Detail Plan (RDTR) of Banjaran Subdistrict stipulates Pasirmulya Village as an Environmental Service Center (PPL) with a directed pattern of space utilization, namely as a settlement, agriculture, plantation and forestry area. The regional characteristics that are directly adjacent to the Puntang Mountain Tourism Area are still characterized by rural areas. Agricultural activities that develop are wetland agriculture with secondary crops. Pasirmulya Village, Banjaran Subdistrict, Bandung Regency, 
West Java Province, has 4 hamlets, 15 RWs and 69 RTs, Pasirmulya Village, located in the highlands which has an area of $+243.1 \mathrm{Ha}$.

The development of tourism in the village of Pasirmulya is directed at the concept of sustainable development, where local communities are given the authority to manage the tourism potential that exists. Likewise, with the presence of tourism facilities. The development of these tourism facilities contributes positively where most local people work in the agricultural sector so that they get economic benefits from

tourism development in their area.

\section{Partner Problems}

Other settlements infrastructure problems faced by Pasirmulya Village are houses that are still less livable with minimal sanitation, damaged road access, channels that have not been arranged, land erosion that continues to occur, toilets that are very inadequate and clean water supply, especially in the dry season water is very difficult to obtain, but there is no pipeline system that can drain water to settlements.

Poverty always creates a variety of problems, but in fact many efforts can be made to reduce it, such as the program that will be carried out on the Pasirmulya villagers. The community service team tries to develop the potential that exists, one of them with natural tourism, to improve the economy of the community in the

Village of Pasirmulya.

Based on the presentation on the situation analysis, there is no proper homestay concept yet, so the formulation of the problem raised is how to create and manage the homestay in Pasirmulya village, in accordance with the nature of the rural-based nature. This concept is called eco-homestay.

\section{Activity Objectives}

This activity aims to organize residents by creating and managing eco-homestays according to standards in the village of Pasirmulya, in accordance with the characteristics of rural areas.

\section{Benefits of Activities}

The benefit of this activity is that it can provide input to the community regarding sustainable ecohomestay development. Understanding for the public about the importance of the eco-home-stay concept. Establishment of uniform product standards for facilities in homes. Positive environmental impact will benefit from eco-homestays. The impact of increasing the economic level of the income for community generated from eco-homestay activities.

\section{Program Solution and Implementation}

According to Law No. 10 of 2009 concerning Tourism Article 14 there are 14 types of service businesses in the tourism sector. One of the tourism services business is accommodation or accommodation. There are several types of accommodation business, namely homestays, guest houses and hotels (jasmine or starred). The accommodation business development will certainly support the development of tourism activities. One tourist attraction that is developing at this time is rural tourism or tourist village. Tourism village is a rural area that has several special characteristics to become a tourist destination which is an integration between attractions, accommodation and other supporting facilities that are presented in a structure of community life that integrates with the prevailing procedures and traditions. Tourists can enjoy the attractions and life of the people by living with the community. Therefore, some residents in tourist villages have prepared their homes as homestays for tourists.

Conservation Village is a community-based biodiversity conservation model that provides opportunities for surrounding communities near protected areas. This kind of model actively involves the community in conservation efforts. This model also provides an opportunity for people to get safe access to land use. Conservation village models ensure their long-term commitment to supporting forest conservation (Berkes, 2004).

Eco-homestays are accommodation facilities in the local ecotourism destination area which are natural, clean, healthy, safe, orderly and environmentally friendly. Eco-homestay business development to diversify the income of local communities by applying the limits of the concept of ecotourism 
development ( (Kaunang, L, \& N, 2012). Eco-homestay is one of the accommodation facilities in ecotourism destinations that are regional (traditional), natural, clean, healthy, safe, orderly and environmentally friendly. So it is impossible for an eco-homestay to be built in a slum area. Ecohomestay development aims to develop the income of the local community by continuing to apply the limits of the concept of ecotourism development. Judging from the operational strategy, the construction of this accommodation facility is one of the techniques to increase the number and duration of tourist visits. In addition, if this eco-homestay is managed with a professional, it will become its own added value which can have a positive impact on the implementation of tourism marketing in the area.

To be able to socialize eco-homestay to the local community can be started by giving counseling about the importance of cleanliness and beauty of the neighborhood. To further provide an overview to them about the benefits that can be obtained through eco-homestay management. Therefore, the pattern of eco-homestay development must be an example home for local communities, in managing clean, healthy and productive homes. Based on the description above, the solution plan for the community service program is as follows:

Table 1 Solution Plan for Pasirmulya Tourism Village

\begin{tabular}{|c|c|c|}
\hline No & Activities & Program Implementation \\
\hline 1. & Promotion & $\begin{array}{l}\text { a) Understanding of eco-tourism-based local } \\
\text { communities } \\
\text { b) Understanding of eco-tourism-oriented } \\
\text { environment } \\
\text { c) Understanding of consistency in the values of } \\
\text { rural tourism and introducing village tourism } \\
\text { potential }\end{array}$ \\
\hline 2. & $\begin{array}{l}\text { Eco-homestay facilities } \\
\text { development. }\end{array}$ & Make decent eco-homestays according to standards \\
\hline 3. & Tourism attraction development & Explore tourism potential in Pasirmulya village \\
\hline 4. & $\begin{array}{l}\text { Improving the quality of human } \\
\text { resources based on local } \\
\text { communities }\end{array}$ & $\begin{array}{l}\text { a) Eco-homestay training } \\
\text { b) Training on understanding the perception of village } \\
\text { tourism }\end{array}$ \\
\hline
\end{tabular}

Based on the activity plan that has been compiled, the expected output targets after implementation, in addition, the results of this activity will also be used to compile outputs in the form of seminars resulting from community service that have been conducted and scientific publications in national journals.

\section{METHOD}

This method of community service starts with Observation, Group Discourse Discussion and Technical Assistant (Sugiyono, 2016). Observations were carried out in the period 17-18 January 2018. The implementation was carried out by visiting Pasirmulya Village with a total of 35 families and visiting 6 houses as materials for upgrading the homestay facilities.

Focus Group Discussion: Establishment of an eco-homestay institution in the form of youth-based eco-homestay management in Pasirmulya village. Implementation on 27-28 April 2018.

Focus Group Discussion: Meeting with existing homestay owners and managers, evaluating activities, management that has been carried out. At this stage it is carried out by visiting all the homestays in Pasirmulya village to continue at the eco-homestay stage.

Training: Preparation of standard operational procedures (SOP).

Homestay Management The homestay management standard preparation procedure (SOP) is conducted by meeting with the homestay owner then discussing the standard operational procedures that can be applied in the homestay in Pasirmulya village. The goal is that the services provided are the same in all existing homestays. In this service activity there are obstacles, because of the busyness of Homestay owners so it is very difficult to meet them. As a solution, community service activities were carried out 
door to door in the sense of visiting each interview homestay and seeing firsthand the work procedures so far.

Training: Submission of tourism-oriented training (Tourism Awareness), aims to increase tourism knowledge.

Technical Assistant: Improved bathroom facilities in 6 houses, where repairs to infrastructure are carried out in the living room, bedroom and bathroom area. It is expected that the assistance can improve understanding of standard infrastructure for homestay operations.

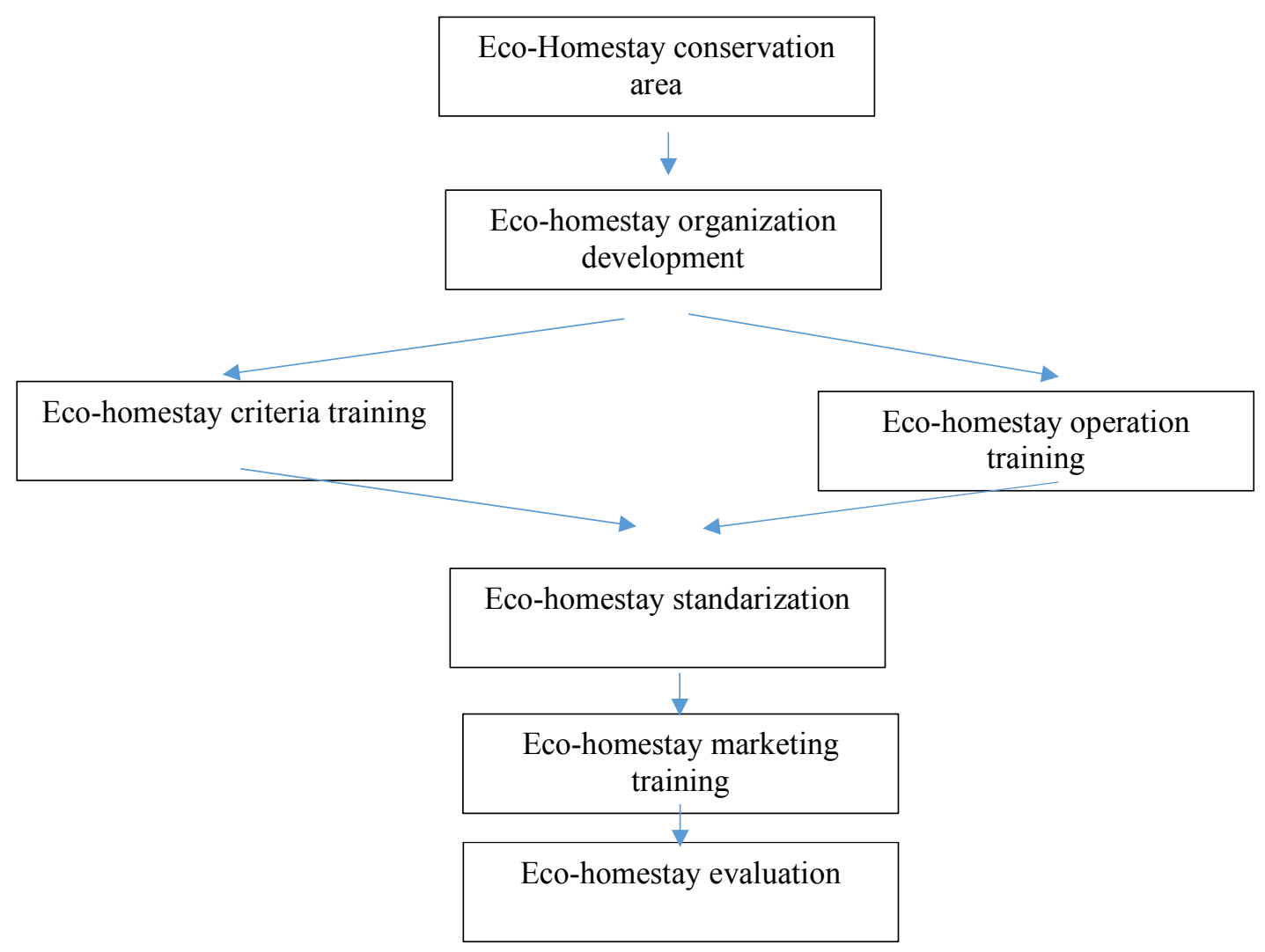

Figure 1. Implementation Method Model

\section{RESULT AND DISCUSSION}

Understanding of eco-homestay after observation is obtained; there is no understanding of ecohomestays and tourism awareness in the village of Pasirmulya. For this reason, training is needed for stakeholders so that public awareness can be improved. The application of eco-homestay can be carried out in stages at the community level. Periodic and periodic activities are needed so that the program can continue.

The steps that must be taken are;

1. Promote the importance of understanding the eco-homestay concept for the Pasirmulya community.

2. Establishing standards for facilities and infrastructure that will make it easier for communities to run eco-homestay programs.

3. Monitoring from Binus University will implement an eco-homestay program. 


\section{Discussion}

It is expected to involve a lot of participation for the community so that the awareness of ecohomestay is improved. New applications for 6 houses that have met the eco-homestay standard. At the village government level, village officials and family heads must have the same enthusiasm in implementing eco-homestays.

\section{CONCLUSION}

Based on the implementation of Eco-homestay development and all the activities at Pasirmulya village, the following results as above:

1. Implementation of eco-homestay standards: implementation of hygiene standards in the homestay area, implementation of standard living in the living room and improvement of bathroom facilities according to standards

2. Understanding the importance of the role of marketing Eco-homestay by increasing understanding of product knowledge, ability to promote the guests visiting Pasirmulya Village

3. Carry out standard communication that helps guests to enjoy the facilities in the village.

\section{REFERENCE}

Berkes, F. (2004). Rethinking community-based conservation. Conservation Biology 18.

Biro Pusat Statistik. (2015). Jumlah Penduduk Miskin Kab/Kota. Jakarta: Biro Pusat Statistik.

Dragulanescu, I. V., \& Drutu, M. (2012). Rural Tourism for Local Economic Development . International Journal of Academic Research in Accounting, Finance and Management Sciences Volume 2, 196-203.

Kaunang, T., L, H., \& N, N. (2012). The uses of ethnobotany for the purposes of ecotourism accomodation: A case study from East Java, Proc. Soc. Indon. Biodiv. Inter. Conf. Solo. Central Java, 227-231.

Kementrian Pariwisata. (2016). Laporan Akuntabilitas Kinerja Kementrian Pariwisata Tahun 2015. Jakarta: Biro Perencanaan dan Keuangan Sekretariat Kementrian Pariwisata.

Sugiyono. (2016). Metode Penelitian Pendekatan Kuantitatif, Kualitatis dan $R \& D$. Bandung: Alfabeta. 